\title{
AUTOMATIC CONCENTRATE DISTRIBUTION FOR FATTENING OF ROMANOV $\times$ DORPER LAMBS
}

Līga ŠENFELDE, Institute of Agrobiotechnology, Latvia University of Agriculture, Lielā iela 2, Jelgava, LV-34001, Latvia, shenfeldel@gmail.com (corresponding author)

Daina KAIRIŠA, Institute of Agrobiotechnology, Latvia University of Agriculture, Lielā iela 2, Jelgava, LV-34001, Latvia, daina.kairisa@llu.lv

\begin{abstract}
The aim of this research was to study the possibility of using automatic concentrate feeding stations in fattening of lambs. Ten Romanov $\times$ Dorper weaned male lambs (initial live weight $21.0 \pm 0.86 \mathrm{~kg}$ ) for fattening were used. Lambs were kept indoors in separate pen and research was carried out in production conditions. Concentrate was distributed for animals individually in automatic feeding station. Adaption period were not applied, eight lambs had the concentrate intake in the automatic feeding station from first research day, one started eat concentrate from third research day and one - from eleventh day of research. The frequency of visits to automatic feeding station and daily concentrate intake was recorded and analyzed. Lamb's were weighted before research and every fourteen days, live weight changes were analyzed. During all the research average number of daily visits to automatic feeding station of one lamb were 13 visits, average daily concentrate intake per animal was: $84 \%$ of the average ration (1642 $\mathrm{g})$ in all research period. Results shows, that average daily live weight gain was $246 \pm 26.3 \mathrm{~g}$, during last quarter daily live weight gain $(89 \pm 27.7 \mathrm{~g})$ was significantly $(\mathrm{p}<0.05)$ lover than in other quarters. For $1 \mathrm{~kg}$ lamb live weight gain $5.39 \mathrm{~kg}$ concentrate was used.
\end{abstract}

Keywords: sheep, live weight gain, feeding, pellets

\section{INTRODUCTION}

The results of lamb fattening can be affected by several factors, such as animal breed and feeding among the main ones. By applying a breeding method, which corresponds to the purpose, animal productivity can be increased up to $40-$ $50 \%$ compared to purebred animals (Leymaster, 2002). The Romanov sheep as dam breed are used for high reproductive purposes and, as a result of crossbreeding with a meet rams, the F1 crossbred lambs have heavier birth weights and weaning weights compared to purebred lambs (Kutluca Korkmaz and Emsen, 2016). Using Dorper breed rams for crossing, F1 crossbreed lambs have a higher dressing percentage and bigger backfat thickness around the longissimus dorsi muscle compared to crossbred lambs of other breeds (Notter et al., 2004; Shackelford, et al., 2015). The importance of proper feeding is evidenced by the research done so far on the influence of frequency of feed distribution (Keskin et al., 2007; Ribiero et al., 2011; Karaca et al., 2016), the fattening systems and feed composition (Aguayo-Ulloa et al., 2013; Ekiz et al., 2013; Boughalmi and Araba, 2016; De Brito et al., 2016) on the live weight gain and carcass traits (weight, dressing percentage). Studies have shown that intensively fattened lambs have a higher carcass weight and dressing percentage if the feed ration contains concentrate in pelleted form and roughage - hay or straw, as compared to lambs, which are fed on pasture grass and receive concentrate feed in the pelleted form or grains (Aguayo- Ulloa et al., 2013; Boughalmi and Araba, 2016). According to the research by Karaca et al. (2016) the lambs that received unlimited quantities of fodder have a lower carcass weight and dressing percentage compared to lambs that received combined feed concentrate 2 or 4 times a day. According to Karaca et al. (2016) and other studies, the feeding of concentrate to lambs was organized from a trough (Aguayo-Ulloa et al., 2013; Boughalmi and Araba, 2016).

The automatic feeding station in sheep feeding could be used for different purposes as: 1) sheep intake recording (Wendl et al., 1999); 2) reduction of concentrate refusals that arises during the meal; 3) avoiding of sheep health problems. During the feed fermentation process the volatile fatty acids and lactic acid arises in rumen. The volatile fatty acids and lactic acid accumulates in the rumen and $\mathrm{pH}$ level remains low under the normal $(8.0-6.5)$ in those cases when animal could not absorb all amount of volatile fatty acids and lactic acid (Plaizier et al., 2009). The first data on automated recording of distribution of concentrate feed to sheep in Latvia was published in 2016 (Šenfelde and Kairiša, 2016).

The aim of this research was to study the possibility of using automatic concentrate feeding stations in fattening of lambs. To achieve the research goal the following tasks were set: 1) to analyze frequency of visits to automatic feeding station; 2) to analyze the amount of concentrate intake; 3) to analyze the lamb live weight changes during fattening.

Copyright (C) 2017 The Authors. Published by Aleksandras Stulginskis University. This is an open-access article distributed under the terms of the Creative Commons Attribution License (CC-BY 4.0), which permits unrestricted use, distribution, and reproduction in any medium, provided the original author and source are credited. 


\section{MATERIALS AND METHODS}

The study about lamb fattening and breeding depending on concentrate distribution manner was carried out on the farm 'Mežoki' located in Latvia $(57.016996,21.632202)$. The study was carried out in production conditions. In total the research was carried out from 16 July 2017 untill 10 September 2017.

Ten male 50\% Romanov $\times 50 \%$ Dorper lambs born in the period from 22 April 2017 untill 9 May 2017 (average age at the beginning and end of study respectively - 77 and 133 days) were used. Lambs were born as triplets ( $n=4$ ), quadruplets $(n=5)$ or quintuplet $(n=1)$. All lambs were weaned and imported in Latvia on 15 July 2017 from Germany, adapting period was not ensured. Until weaning the lambs and their mothers were kept on pasture and had not received any concentrate. Live weight of lambs before this study was not significantly different $(\mathrm{p}=0.148)$, average live weight of lambs was $21.0 \pm 0.86 \mathrm{~kg}$. During the research lambs were kept apart in a separate pen and provided continuous access to an automatic concentrate feeding station. The lambs were given free access to water as well. At the automatic feeding station lambs were offered concentrate of the following content: $46 \%$ of cereals (barley (Hordeum vulgare L.), maize (Zea mays), wheat (Triticum), wheat (Triticum) bran), $36 \%$ plant-based protein sources (feed beans (Vicia faba), sunflower (Helianthus annuus) coarse meal, rapeseed (Brassica napus) meal) and $18 \%$ the remaining ingredients (oats (Avena sativa), lime flour, molasses - liquid, $\mathrm{NaCl}$ ). Concentrate content: $84 \%$ of dry matter (DM), protein $20.4 \%$ in DM, crude fibre $8.2 \%$ in DM, metabolizable energy (ME) $10.48 \mathrm{MJ} \mathrm{kg}^{-1}$ of DM, neutral detergent fibre (NDF) $24 \%$ in $\mathrm{DM}$, acid detergent fibre (ADF) $11 \%$ in DM, P $0.59 \%$ in DM, Ca $1.66 \%$ in DM. Under the study the daily concentrate feed rations for one animal were determined steadily increasing from $1510 \mathrm{~g}$ (17 July 2017$)$ to $1780 \mathrm{~g}$ (10 September 2017).

Live weight monitoring of lambs was organized with a New Zealand company's Tru-Test automatic weigh scales. Weighing accuracy is $\pm 0.1 \mathrm{~kg}$ for animals with live weight up to $50 \mathrm{~kg}$ and $\pm 0.2 \mathrm{~kg}$ for animals with live weight 50 100 kg. Live weight control dates: 16 July 2017, 30 July 2017, 13 August 2017, 27 August 2017, 10 September 2017.

Concentrate distribution was organized using BioControl Norway JSC compound concentrate feeding station for feeding of individual sheep, identically as for the research made in 2015 (Šenfelde and Kairiša, 2016; Šenfelde and Kairiša; 2017). The external measurements of the feeding station are $2 \times 8 \times 1 \mathrm{~m}$, its mode of operation - continuous. Form of the concentrate feed - pellets. One standard dose dispensed in the feeding station $-25 \mathrm{~g}$, maximum limit intake at one visit to the feeding station $-100 \mathrm{~g}$. Using the concentrate feeding station the following data were recorded: electronic ID number of the animal visiting the feeding station, date and time of the visit to the feeding station for each lamb, the amount of concentrate dispensed per visit, the amount of concentrate dispensed per day for each lamb after each visit, total concentrate amount for each lamb per day. The data from the concentrate feeding station were collected from 17 July 2017 untill 10 September 2017, except 9 August 2017 when there was a failure in power supply. The obtained data were analyzed in the periods between live weight controls: from 17 July 2017 to 30 July 2017 ( $1^{\text {st }}$ period), from 31 July 2017 to 13 August 2017 ( $2^{\text {nd }}$ period), from 14 August 2017 to 27 August 2017 ( $3^{\text {rd }}$ period) and from 28 August 2017 to 10 September 2017 (4 $4^{\text {th }}$ period).

The data were analyzed with mathematical processing methods, using software 'SPSS Statistics'. The number of visits, quantity of compound concentrate fed, live weight mean values of lambs, standard error, coefficient of variation and the concentrate quantity necessary for $1 \mathrm{~kg}$ live weight gain were calculated. The amount of concentrate necessary for live weight gain of $1 \mathrm{~kg}$ was calculated dividing the total amount of concentrate $(\mathrm{kg})$, which was fed, by the live weight gain $(\mathrm{kg})$. The Parameters obtained were compared between study periods, determining significance of their differences and designating with the upper-case alphabetical character; A, B, C p $\leq 0.05$.

\section{RESULTS AND DISCUSSIONS}

Lambs were not applied an adaption period so that they would get accustomed to the concentrate feeding station and manner of concentrate distribution, while the records of the feeding station show that from the 11th day of research the concentrate feeding station is visited by all lambs. On the first and second day of research 2 lambs did not visit the feeding station and from the third to 10th day (including) one lamb did not visit the visit the feeding station. This explains the minimum number of visits ( 0 visits) in the 1 st period (Table 1$)$. On average, throughout the study, each lamb visited the feeding station 13 times per day. The lowest number of visits was during the 4th period (10 visits) and the first period (11 visits), which is significantly different $(\mathrm{p}<0.05)$ from the average number of visits per day (15 visits) in the 2 nd and 3 rd period (Table1). The highest number of lamb visits per day was recorded during the 2nd and 3rd periods (29 visits), but during the whole study period lambs mostly visited the feed station 10 times per day. In this study, both the average and the maximum number of visits to the feeding station is higher than in the study conducted in 2015 (6 and 14 visits respectively) (Šenfelde and Kairiša, 2017), which is explained by the daily concentrate ration $(300 \mathrm{~g}-700 \mathrm{~g})$, the size of the study group (48-136 animals) and there were sheep for breeding used. Although the average number of visits at the feeding station is different, both studies indicate that mode and median of the number of visits are equal or close to each other.

A significant difference from the previous study (Šenfelde and Kairiša, 2017) is that in this study the feeding station was visited by all lambs, unlike the previous results when from $13 \%$ to $49 \%$ of sheep did not attend the feeding station to consume concentrate that could be explained by difference of group size and age of animals. In 2015 sheep for breeding were used, not for fattening. The variation factor in this study ranges from $24 \%$ to $49 \%$ indicating that lambs do not visit the feeding station regularly, which coincides with the previous results (Šenfelde and Kairiša, 2017) 
Table 1. Daily number of visits to the automatic feeding station per lamb

\begin{tabular}{|l|c|c|c|c|c|c|}
\hline Period & $\overline{\mathrm{X}} \pm \mathrm{S}_{\overline{\mathrm{X}}}$ & Min & Max & Median & Mode & V\% \\
\hline 1 & $11 \pm 0.5^{\mathrm{A}}$ & 0 & 24 & 12 & 14 & 49 \\
\hline 2 & $15 \pm 0.4^{\mathrm{B}}$ & 4 & 29 & 14 & 16 & 34 \\
\hline 3 & $15 \pm 0.4^{\mathrm{B}}$ & 5 & 29 & 14 & 10 & 33 \\
\hline 4 & $10 \pm 0.2^{\mathrm{A}}$ & 3 & 17 & 10 & 10 & 24 \\
\hline Total & $13 \pm 0.2$ & 0 & 29 & 12 & 10 & 40 \\
\hline
\end{tabular}

${ }^{A B}$ - traits with different subscriptions are significantly different $(\mathrm{p}<0.05)$

Throughout the study period the lambs received an average of $1378 \pm 16.1 \mathrm{~g}$ concentrate (Table 2) per day. Analyzing by periods, the average daily intake of concentrate was in the range from $1171 \pm 40.1 \mathrm{~g}$ (in the $1 \mathrm{st}$ period) to $1483 \pm 20.2 \mathrm{~g}$ (in the $3 \mathrm{rd}$ period). The average amount of feed intake differed significantly $(\mathrm{p}<0.05)$ in the 1 st period $(1171 \pm 40.1 \mathrm{~g})$, which could be explained by adaption of lambs to the new conditions. Although the average daily concentrate intake in the $2 \mathrm{nd}, 3 \mathrm{rd}$ and 4 th period in comparison with the previous period was increased by $4.5 \%$, $4.6 \%$ and $3.9 \%$ respectively, the actual lamb average daily concentrate intake in comparison with the previous periods $-2 \mathrm{nd}$, 3rd and 4th - was $23 \%, 3 \%$ and $-3.4 \%$, respectively. On average, the concentrate intake by lambs was $76 \%, 90 \%, 88 \%$ and $82 \%$ of the determined average daily ration during the $1 \mathrm{st}$, 2nd, 3rd and 4th period of research respectively, while it was $84 \%$ of the average daily concentrate ration throughout the study.

The maximum amount of feed intake during the 1st, 2nd and 3rd periods exceeded the permissible level by $5 \mathrm{~g}$ (in the 1 st and 2nd period) - $10 \mathrm{~g}$ (in the 3rd period), which can be explained by the settings of the feeding station software, because the metering unit dispensed the dose $(25 \mathrm{~g})$ also if less than $25 \mathrm{~g}$ were left unconsumed of the determined daily intake ration.

The analysis of the amount of concentrate intake and live weight gain indicates that the lowest amount of concentrate $(2.95 \mathrm{~kg}$ ) was needed to achieve $1 \mathrm{~kg}$ live weight gain during the 1 st study period, but the highest amount $(14.83 \mathrm{~kg}$ ) was necessary in the 4th period of research. On the average throughout the research $5.39 \mathrm{~kg}$ of concentrate for $1 \mathrm{~kg}$ lamb live weight gain was used, which is less compared to concentrate intake (7.0-7.9 kg) necessary for Dorper purebreds $1 \mathrm{~kg}$ live weight gain (Brand et al., 2017). Also the results of the fattening of the lambs of the cross between Romanov and Dorper breeds offering concentrate in trough, showed a higher consumption of concentrate for $1 \mathrm{~kg}$ live weight gain $(6.4 \mathrm{~kg})$ (Barzdina and Kairiša, 2016).

Table 2. Daily concentrate ration and intake per lamb, g

\begin{tabular}{|c|c|c|c|c|c|c|c|}
\hline \multirow[b]{2}{*}{ Period } & \multicolumn{3}{|c|}{ Ration } & \multicolumn{4}{|c|}{ Intake } \\
\hline & Min & Max & $\overline{\mathrm{x}}$ & $\bar{x} \pm S_{\bar{x}}$ & Min & Max & $\begin{array}{c}\text { Concentrate necessary } \\
\text { for } 1 \mathrm{~kg} \text { live weight gain, } \\
\mathrm{kg}\end{array}$ \\
\hline 1 & 1510 & 1570 & 1538 & $1171 \pm 40.1^{\mathrm{A}}$ & 0 & 1575 & 2.95 \\
\hline 2 & 1575 & 1645 & 1608 & $1440 \pm 23.9^{\mathrm{B}}$ & 550 & 1650 & 6.56 \\
\hline 3 & 1650 & 1715 & 1682 & $1483 \pm 20.2^{\mathrm{B}}$ & 750 & 1725 & 5.00 \\
\hline 4 & 1720 & 1780 & 1749 & $1426 \pm 32.9^{\mathrm{B}}$ & 425 & 1775 & 14.83 \\
\hline Total & 1510 & 1780 & 1642 & $1378 \pm 16.1$ & 0 & 1775 & 5.39 \\
\hline
\end{tabular}

$\mathrm{AB}$ - traits with different subscriptions are significantly different $(\mathrm{p}<0.05)$

Throughout the study the average live weight of lambs was $13.9 \pm 0.37 \mathrm{~kg}$ (Table 3), the average live weight gain was $246 \pm 26.3 \mathrm{~g}$ per day, which is less compared to the fattening of lambs of the cross of Romanov and Dorper breeds by offering concentrate in a trough (291.9 g) (Barzdina and Kairiša, 2016). The results of fattening of Dorper purebred lambs are indicative of different lamb average daily live weight gain from $134 \mathrm{~g}$ to $285 \mathrm{~g}$ (Brand et al., 2017) and from $62 \mathrm{~g}$ to $166 \mathrm{~g}$ (Zishiri et al. (2013). It shows that the genetic characteristics of ram are important too. In this research the highest live weight gain was observed in the 1 st research period $(5.6 \pm 0.63 \mathrm{~kg}$ throughout the period and $395 \pm 44.4 \mathrm{~g} /$ day) and it was significantly different $(\mathrm{p}<0.05)$ from the live weight gain in the 2nd and 4th periods $(204 \pm 44.8 \mathrm{~g}$, respectively, and $89 \pm 27.7 \mathrm{~g}$ perday). The lowest live weight gain was in the 4 th research period $(13 \pm 0.39 \mathrm{~kg}$ throughout the period and $89 \pm 27.7 \mathrm{~g}$ per day), which differed significantly $(\mathrm{p}<0.05)$ from live weight gain in the other research periods.

Table 3. Live weight changes of lambs

\begin{tabular}{|c|c|c|c|}
\hline \multirow{2}{*}{ Live weight control dates } & Live weight, $\mathrm{kg}$ & \multirow{2}{*}{ Live weight differences, $\mathrm{kg}$} & Live weight gain per day, $\mathrm{g}$ \\
\hline & $\overline{\mathrm{x}} \pm \mathrm{S}_{\overline{\mathrm{x}}}$ & & $\overline{\mathrm{x}}$ \\
\hline 16 July 2017 (before research) & $21.0 \pm 0.86^{\mathrm{A}}$ & - & - \\
\hline 30 July 2017 (after $1^{\text {st }}$ period) & $26.6 \pm 0.76^{\mathrm{B}}$ & $5.6 \pm 0.63^{\mathrm{A}}$ & $395 \pm 44.4^{\mathrm{A}}$ \\
\hline 13 August 2017 (after $2^{\text {nd }}$ period) & $29.5 \pm 0.70^{\mathrm{B}}$ & $2.9 \pm 0.63^{\mathrm{B}}$ & $204 \pm 44.8^{\mathrm{B}}$ \\
\hline 27 August 2017 (after $3^{\text {rd }}$ period) & $33.6 \pm 0.93^{\mathrm{C}}$ & $4.1 \pm 0.56^{\mathrm{AB}}$ & $297 \pm 39.5^{\mathrm{AB}}$ \\
\hline 10 September 2017 (after $4^{\text {th }}$ period) & $34.9 \pm 0.91^{\mathrm{C}}$ & $1.3 \pm 0.39^{\mathrm{C}}$ & $89 \pm 27.7^{\mathrm{C}}$ \\
\hline \multicolumn{2}{|l|}{ Total } & $13.9 \pm 0.37$ & $246 \pm 26.3$ \\
\hline
\end{tabular}

$\mathrm{ABC}$ - traits with different subscriptions are significantly different $(\mathrm{p}<0.05)$ 


\section{Proceedings of the $8^{\text {th }}$ International Scientific Conference Rural Development 2017}

In general, the results of the study indicate that the last two research weeks (4th period) of the livestock fattening period and use of the concentrate feeding station were the most non-productive - the daily number of visits to the feeding station was the smallest (10 visits) (Table 1), the average daily concentrate intake was lower (1426 $\pm 32.9 \mathrm{~g})$ than that in the 2 nd and 3rd period ( $1440 \pm 23.9 \mathrm{~g}$ and $1483 \pm 20.2 \mathrm{~g}$ respectively) (Table 2$)$, and the average live weight gain per day was the lowest $(89 \pm 27.7 \mathrm{~g})$ Table 3$)$. This could be explained by influence of both the breed and nutritional factors that are not being analyzed in this study and indicates that in this research lambs had reached their peak productivity already at the end of the 3rd research period (27 August 2017). Also, Brand et al. (2017) indicates that Dorper lambs should be slaughtered at less live weights.

\section{CONCLUSIONS}

1. During the study, there were no animal health concerns related to the amount and frequency of feed intake. The results show that the concentrate feeding station can be used also to obtain the data needed to determine the optimum fattening period for lambs before slaughter.

2. The average number of daily visits to the concentrate feeing station was 13 visits, the most frequently recorded number of visits per day was 10 visits by an animal, but the highest number of visits was 29 visits per day. The number of visits to the feeding station in 24 hours between animals was different; the variation coefficient was $40 \%$.

3. At the feeding station on average the lambs consumed $1378 \pm 16.1 \mathrm{~g}$ concentrate daily which amounts to $84 \%$ of the determined average daily ration. During the research an average of $5.39 \mathrm{~kg}$ of concentrate was used for $1 \mathrm{~kg}$ live weight gain, and the highest consumption of concentrate per $1 \mathrm{~kg}$ of live weight gain was in the 4th research period $(14.83 \mathrm{~kg})$.

4. During the research lamb average live weight gain was $13.9 \mathrm{~kg}$, while the average daily live weight gain was $246 \pm 26 \mathrm{~g}$.

\section{REFERENCES}

1. Aguayo-Ulloa, L. A., Miranda - de la Lama, G. C., Pascual-Alonso, M., Fuchs, K., Olleta, J. L., Campo, M. M., Alierta, S., Villarroel, M., Maria, G. A. 2013. Effect of feeding regime during finishing on lamb welfare, production performance and meat quality. Small Ruminant Research, Vol. 111, pp. 147-156. https://doi.org/10.1016/j.smallrumres.2012.09.011

2. Barzdina, D., Kairiša, D. 2016. Fattening results analysis of Romanov and Dorper crossbred lambs. SGEM2016 Conference Proceedings, Vol. 3, Book 6, pp. 65--664, SGEM Vienna GREEN Extended Scientific Sessions.

3. Boughalmi, A., Araba, A. 2016. Effect of feeding management from grass to concentrate feed on growth, carcass characteristics, meat quality and fatty acid profile of Timahdite lamb breed. Small Ruminant Research. Vol. 144, pp. 158-163. https://doi.org/10.1016/j.smallrumres.2016.09.013

4. Brand, T. S., Van der Westhuizen, E. J., Van der Merwe, D. A., Hoffman, L. C. 2017. Effect of days in feedlot on growth performance and carcass characteristics of Merino, South African Mutton Merino and Dorper lambs. South African Journal of Animal Science, Vol. 47, No. 1, pp. 26-33. https://doi.org/10.4314/sajas.v47i1.5

5. De Brito, G. F., McGrath, S. R., Holman, B. W. B., Friend, M. A., Fowler, S. M., Van de Ven, R. J., Hopkins, D. L. 2016. The effect of forage type on lamb carcass traits, meat quality and sensory traits. Meat Science, Vol. 119, pp. 95-101. h https://doi.org/10.1016/j.meatsci.2016.04.030

6. Ekiz, B., Demirel, G., Yilmaz, A., Ozcan, M., Yalcintan, H., Kocak, O., Altinel, A. 2013. Slaughter characteristics, carcass quality and fatty acid composition of lambs under four different production systems. Small Ruminant Research, Vol. 114, No 1, pp. 26-34. https://doi.org/10.1016/j.smallrumres.2013.05.011

7. Karaca, S., Yilmaz, A., Kor, A., Bingöl, M., Keskin, S. 2016. Effect of different feeding systems on the fattening performance, slaughter-carcass characteristics and meat quality in lambs. Indian Journal of Animal Research, Vol. 50, No 4, pp. 595-600. https://doi.org/10.18805/ijar.9377

8. Keskin, M., Gül, S., Şahin, A., Kaya, Ş., Duru, M., Görgülü, Ö ., Sahinler, S., Biçer, O. 2007. Effects of feed refreshing frequency on growth and carcass characteristics of Awassi lambs. South African Journal of Animal Science, Vol. 37, No 4, pp. $248-255$. https://doi.org/10.4314/sajas.v37i4.4097

9. Kutluca Korkmaz, M., Emsen, E. 2016. Growth and reproductive traits of purebred and crossbred Romanov lambs in Eastern Anatolia. Animal Reproduction, Vol. 13, No. 1, pp. 3-6. https://doi.org/10.4322/1984-3143-AR722

10. Leymaster, K. A. 2002. Fundamental Aspects of Crossbreeding of Sheep: Use of Breed Diversity to Improve Efficiency of Meat Production. Sheep and Goat Research Journal, Vol. 17, No 3, pp. 50-59.

11. Notter, D. R., Greiner, S. P., Wahlberg, M. L. 2004. Growth and carcass characteristics of lambs sired by Dorper and Dorset rams. Journal of Animals Science, Vol. 82, No 5, pp. 1323-1328. https://doi.org/10.2527/2004.8251323x

12. Plaizier, J.C., Krause, D.O., Gozho, G.N., McBride, B.W. 2009. Subacute ruminal acidosis in dairy cows: the physiological causes, incidence and consequences. The Veterinary Journal, Vol. 176, pp. 21-31. https://doi.org/10.1016/j.tvjl.2007.12.016

13. Ribeiro, E. L. A., Mizubuti, I. Y., Silva, L. D. F., Paiva, F. H. P., Sousa, C. L., Castro, F. A. B. 2011. Performance, ingestive behavior and carcass characteristics of feedlot lambs submitted to different feeding frequencies. Revista Brasileira de Zootecnia, Vol. 40, No 4, pp. 892-898. https://doi.org/10.1590/S1516-35982011000400025

14. Šenfelde, L., Kairiša, D. 2016. Use of automatic fodder feeding station for feeding of young sheep. In: Proceedings of the Scientific and Practical Conference "Harmonius Agriculture", Jelgava, Latvia, 25-26 May 2016, Latvia University of Agriculture, pp. 189-192.

15. Šenfelde, L., Kairiša, D. 2017. Concentrate distribution to sheep using automatic feeding station. 23rd Annual International Scientific Conference "Research for Rural Development 2017", Latvia University of Agriculture, Jelgava, Latvia 17-19 May 2017 
16. Shackelford, S. D., Leymaster, K. A., Wheeler, T. L., Koohmaraie, M. 2015. Effects of breed of sire on carcass composition and sensory traits of lamb. Journal of Animals Science, Vol. 9, No 11, pp. 4131-4139.

17. Wendl, G., Wendling, F., Wagner, M., Pirkelmann, H. 1999. A feed station for automatic recording of sheep intake. Landtechnik, Vol. 54, No 5, pp. 304-305.

18. Zishiri, O. T., Cloete, S. W., Olivier, J. J., Dzama, K. 2013. Genetic trends for objectively measured and subjectively assessed traits in a Dorper sheep flock. Tropical Animal Health and Production, Vol. 45, No 2, pp. 517-524. https://doi.org/10.1007/s11250-012$\underline{0251-9}$ 